\title{
Sexuality In Dangdut Lyrics: A Critical Discourse Analysis
}

\author{
Slamet Setiawan', Aprilia Susanti ${ }^{2}$ \\ ${ }^{1,2}$ State University of Surabaya \\ slamet.setiawan@unesa.ac.id
}

\begin{abstract}
Dangdut is claimed to be the original music genre of Indonesia has been undergoing radical change lately in both rhythm and lyric. The latter is manifested into sub-genre called dangdut koplo which manipulates the rapid beat of ketipung 'tom-tom'. The latter is expressed by altering message of the lyric to be blatant vulgar which leads to sexuality. This study investigated mainly on the latter case; the language expression and linguistic features used in dangdut lyric to exploit sexuality, the form of relation among the participants, and socio-cultural phenomena reflected within dangdut lyric with sensual content. The qualitative analysis using Critical Discourse Analysis (CDA) proposed by Fairclough (1995) were used to be the conceptual framework. There were 19 controversial dangdut songs lyric considered as sensual and exploit sexuality were taken as the source of the data and twenty listeners were interviewed. The results of the study show that: Firstly, the lyrics employed Bahasa Indon esia and Javanese, figurative language in both dialogue and monologue, narrative text, rhymes, rhetorical question, seducing expression, and incomplete sentence structure. Secondly, the songs talked about man and woman relationship, sensual desire, and gender stereotype. Finally, the songs concern on the justifiability of the sensual content and economy motive. Besides, free sex and gender stereotype are the reflection of sociocultural phenomena.
\end{abstract}

Key words: dangdut, CDA (Critical Discourse Analysis), micro level, messo level, macro level

\section{INTRODUCTION}

Dangdut is an original musical genre from Indonesia. The form of dangdut which emerged as a legendary genre has started within 1960s. Dangdut was created through the blending of Indian-derived orkes Melayu with the sounds and attitudes of US-American and British rock ' $n$ ' roll (Decker, 2016). Roma Irama, who is claimed as the king of dangdut, in Weintraub (2010) mentioned that dangdut has become popular because dangdut related deeply with the soul of indigenous people of Indonesians (Barker \& Barker, 2011). Dangdut is the music of lowermiddle class of Indonesians (Campbell, 1998 in (Rahayu, 2018)). The audience of dangdut are presented mostly as the common people or in some cases they are claimed as an uneducated people (Putri, 2018) Within the first decade of dangdut,, it represented positive lyrics contained moral value and examples of good manner. However, the naturality of dangdut has changed. The changes of dangdut is significantly obvious from the subgenre of it, which is dangdut "koplo". Dangdut koplo can be distinguished from other music genre through the music rhythm composition. The beat is faster equated with conventional dangdut music. In the musical instrument dangdut drum (kendang) that sounds "dang" dominates compared with the sound of "dut" and this sound can be produced by making sounds with dragging the hand on the drum membrane surface (Tandho \& Rohidi, 2018). Beside, another changes as Deyoung (2018) commented that dangdut nowadays contains with sexual exploration of women. The shift of dangdut was firstly noted from the performance of "Inul Daratista", a woman singer who performed in media with her "goyang ngebor" or drilling dance (Johan, 2018). The performance of Inul activated polemic and national debate about the democracy showing women's bodies, the freedom expression of sexuality and the role of censorship (Putri, 2018).

Dangdut has formed into its stereotype as a vulgar music which is sung by many female singers who arise within their glamorous 
performance and sexual exposure in music industry, but these fact has lead dangdut into its commercialization in the industry (Johan, 2018). Mostly dangdut performers are female singers and the predominantly dancing audience are male who are the mostly satisfied of the music because they feel like their desires have burned up (Eight, 2014). Within their dancing, dangdut performer are usually be the object of sexuality through the "nyawer" encounter. This practice is mostly occur in the village performer. "Nyawer" is the money delivering by the dancing audience to the singer and while doing this, the dancing audience can put the money to the body part of the singers or even this can be the sign to "buy" the singer for the sexual encounter (Bader, 2011). Wallach (2003) oh his study in Jakarta found that,

"Dangdut, performances take place on any given night, but whether they occur in a smoky, darkened nightclub, at a wedding celebration in a cramped urban backyard, or in front of thousands of revelers at a large outdoor festival, the female singer-dancers at dangdut concerts interact in similar ways with their largely male audiences" (Wallach, 2003).

Meanwhile, talking about Dangdut lyrics which was contains with good value and religious matter has shifted and mostly put woman into the center of exploration about sexual and social discussion against national moral values (Decker, 2016). Dangdut lyrics is claimed as not good as it used to be and encompasses unqualified lyrics(Sari \& Hanum, 2018). Below are some examples of the erotically lyrics on the popular dangdut song:

Aku pengen pentol sing ono mie-ne translated as 'I want meatball served with noodle' may not be merely understood as the way it is. This may not talk about culinary. It could refer to something else as sensuality and erotic desire, for instance. This interpretation may not value free. However, such interpretation may distinguish one text with another based on the socio culture within its social context.

The above example is taken from a song lyric in Dangdut music. As text is defined as cultural artifact (Street \& Lefstein, 2007), song lyric is also a cultural artifact. It is a product that is shaped and is shaping a particular community. Text is a part of social interaction (Wodak, Ruth and Meyer, 2001). It involves transactional ideology within power relation.

Text is element of social event. It carries meaning and value. It brings about changes in knowledge, belief, action, values, social interaction. These impacts are facilitated by meaning-making (Fairclough, 2003). People respond to text differently according to their interpretation and what it meant to them. It is because they have their own ways of thinking and perspective.

Meanwhile, language is a social phenomenon. Kress (1989) in Wodak ( 2001) argues that not only individuals, but also certain community has specific meanings and values, which expressed in language in systematic ways. While Fairclough (2003) asserts that language which is a part of social life, is interconnected to other elements of social life. It means that language is a part of social life and connected with other elements of it.

The relation between text and language can be seen in Kress (1989) in Wodak (2001) that define text as the relevant units of language in communication. Text is used to communicate the ideology, perspective, belief, thought and even feeling. Text is a media to interact with society in systematic way.

Thus, in order to analyze texts, it may not work within a border of linguistic analysis only, but also include 'interdiscursive analysis'(Fairclough, 2003). In analysis text, it may refer to its different and specific discourses, genres and style that influence each other. Text is a product of particular 
social construction and social practices we should refer to.

A study in Dangdut Lyric has previously done by Rachmawati (2012). In her study, she investigated the interpretation of Dangdut song lyric. She was analyzing only one Dangdut song entitled Mobil Bergoyang. However, she organized the analysis within the semiology framework by Barthes (1972). Later, she found out the meaning of pornography that leads to free sex that occurs in social life is reflected in the song.

An interpretative focus on a song has been the main focus of research done by Handforth et al. (2017). They interrogate people interpretation on Blurred Lines song. She used qualitative analysis from corpus linguistics. The result show that most listeners either interpreted the songs as take sexual consent, or it was simply representative of the genre and found it unproblematic. However, the song is not Dangdut song as will be investigated in this study.

However, this study analyzes the language expression in Dangdut lyrics to seek sexuality content through CDA. A framework to analyze text with a high consideration of language as social practice is through critical discourse analysis (CDA). In CDA, the context of language is valued high and is vital (Wodak, Ruth and Meyer, 2001). CDA can be the tool to investigate social practice. For example, a research to interpret a racial literacy was done by Rogers and Mosley (2008).

In order to analyze text, Fairclough (1995) characterized CDA in three well-known dimensions. They are text analysis, discourse practice analysis and discursive analysis. Furthermore, he distinguished text interpretation into three levels. Firstly, the text is analyzed according to the linguistic features, grammatical system, and other language elements; the micro level of CDA. Secondly, the messo level investigates the social agents, the participants who are involved in social events. It refers to people who make meaning and also social event (when, what and where). Thirdly, the macro level involves intertextuality of the text. It connects to social phenomena or social event as a representation of social practices. There are three points to address in this study. 1) The language expression and linguistic feature used in Dangdut lyric to exploit sexuality, 2) the form of relation among the participants, and 3) Socio cultural phenomena reflection within Dangdut lyric with sensual content.

\section{THEORETICAL FRAMEWORK}

Critical discourse analysis (CDA) initially circulated in the mid-1980s. It sets new direction for linguists based on the work of Fairclough, van Dijk, Wodak, and others (Leeuwen, 2006). This approach focuses on the sociocultural relationship of text within its discourse and context. It articulates between discourse and social practice. It values on critical social theory. Here, CDA is reflexive (Flowerdew, 1999).

CDA concerns on 'language as social practice' (Fairclough and Wodak, 1997), and context of a language is very vital (Wodak and Meyer, 2001). It may cause misinterpretation or further misunderstanding if context is neglected. Context is a seedbed for meaning making. It is a space where meaning comes to live. The distinction of CDA over other methods lies on the intertextuality and interdiscursivity. In CDA, text is analyzed further considering its relationship with other texts. There is connection between sociocultural practice and text that is mediated by discourse practice; how a text is produced or interpreted (Fairclough, 1995).

A theorization and description of social process and structure is needed for a critical discourse (Wodak and Meyer, 2001). It will give exposure for text production and social structure where meaning making occurs in interpretation with texts. What happen in society as culture and ideology embedded is taken into account. Thus, meaning will be produced. 
Discourse is shaped by dominance (Wodak and Meyer, 2001). Every discourse is historically produced and interpreted. It is situated in time and space. The dominance structures are legitimated by ideologies of powerful groups. The ideology, hierarchy and gender, sociocultural system is the elements of interpretation of text. CDA is "a type of discourse analysis study that primarily studies the way social power abuse, dominance, and inequality are enacted, reproduced, and resisted by text and talk in social and political contexts" (van Dijk, 2004 in (Sriwimon \& Jimarkon, 2017).

Furthermore, Fairclough (1993) argues that discourse is 'socially constructive'. It puts consideration on social change. Social process is unstable. It moves dynamically. Therefore, discourse is also dynamic and historically situated. Interpretation can only be made within the time and place where text is produced.

Fairclough (1993) proposed three dimensions of discourse practice. Intertextuality refers to text production. Intertextual chain refers to text distribution. Coherence refers to text consumption. It is how texts are actually interpreted. Later on, in his study, Fairclough (1995) distinguished three dimensional method of discourse analysis. Firstly, the linguistic description of the text, both spoken and written. Secondly, discourse practice that refers to text production and text interpretation. It explains the connection between the discursive process (production and interpretation) and the text. Thirdly, sociocultural practice. The connection between sociocultural practice and text is mediated by discourse practice, how text is produced or interpreted. This study goes along this framework.

\section{METHOD}

This is a qualitative study which examines how language expressions related to sexuality are linguistically generated in Dangdut lyrics. It used CDA as an analytical framework to see: 1) The language expression and linguistic feature used in Dangdut lyric to exploit sexuality, 2) the form of relation among the participants, and 3) Socio cultural phenomena reflection within Dangdut lyric with sensual content. The three points will be further analyzed through CDA with three graded level of interpretation. In addressing the second point, interview is done to see people perspective of vulgar Dangdut lyric. Moreover, it explores relational form of participants.

There are 19 Dangdut koplo songs have been taken for further analysis, "Mobil Bergoyang", "Paling suka 69", "Belah Duren", "Kebelet", "Lelaki Kardus", "Mucikari Cinta", "Becekin aku bang", "Tali Kutang", "Pengen Dibolongi", "Hamil Duluan"and so on. These 19 song lyrics are the top listed google search considered as vulgar or sensual. These data are collected through internet. The lyrics are, then, observed and categorized. Those songs then analyzed through three dimensional level of interpretation from Norman Fairclough work; micro-, messo-, and macro-structure.

The first research question will be further analyzed through micro-structure level of interpretation. It investigates the language expression, language feature, style, grammatical level and other elements of language. The second research question deals with messo-structure which explore on the production, consumption and distribution of texts. This discourse analysis reveals the ideology and power that is 'obscure' (Wodak and Meyer, 2001). There must be something behind the text production over its consumption. The third research question seeks correlation between text and other texts, intertextuality concept. This macro-structure deals with sociocultural practice. It regards how social context shapes discourse in a text (Setiawan \& Halum, 2016).

\section{DISCUSSION}


Language expression and language feature in Dangdut lyric: Micro level

This level of analysis provides language expression, language feature and other elements. There are seven points addressing this notion. The song lyrics use both Bahasa Indonesia and Javanese, figurative language, dialogue and monologue, narrative text, rhymes, rhetorical question, seducing expression, and incomplete sentence structure.

Over 19 Dangdut songs used in this study, there are 13 songs in Bahasa Indonesia. The rests use Javanese, a local language. Using local language, yet Indonesian netizens are familiar with those songs, though. The six Javanese songs are those which hit national top charts.

Figurative language aims at aesthetical reason and conveying meaning in different stylistic language. Metaphor is used to find the similarity of one object and the other. In Lelaki Kardus, the title and the last part of the lyric use metaphor that find similarity between a man and an item. It said lelaki kardus, lelaki karpet. The metaphor is used to express anger to a man. Thus, the man is represented with useless item as paper box and mat. Then, Personification is also used. It personifies an item with human behavior or act. Mobil Bergoyang is one of the titles. It personifies a car that dance. Symbolism is found mostly in many song lyrics. Number ' 69 ' symbolizes a sexual position in Kamasutra. The song Paling Suka 69 talks about a sexual symbol according to Indian sexology. It is, moreover, explained explicitly within the lyrics stated "Irama gaya kamasutra ala india". A title Tali Kutang is actually symbolizes love, take and give. However, choosing woman's underwear as the symbol of love is quite intriguing. The title Wanita Lubang Buaya conveys symbolism. Lubang buaya refers to woman's genital. It is defined in the lyric "wanita punya satu lubang. Walau satu tapi itu sangat berharga". The writer of the song asserts that woman possess only one precious 'hole'; the genital. A Javanese
Dangdut song entitled Ngidam Pentol symbolizing men's testis as meatball or pentol. The title Belah Duren refers to sexual intercourse. In the lyric the practice is described in detail. The time of malam pengantin, in a locked room mengunci pintu, with Paling enak dengan kekasih a loved one is finely explained. Among those title of songs, one of the song was firstly sung and launched by a child under 15 years old, the title is Lelaki Kardus.

In Lelaki Kardus the lyrics contains:

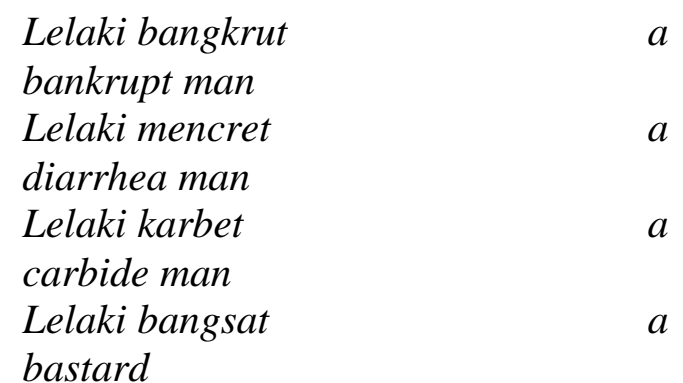

The lyrics of Lelaki Kardus represent a Sarcasm. It shows some impolite mocking toward the father to show the anger of the child after the father married to another woman. This depicted how dangdut engages in young generation of Indonesia where actually politeness is a must in the social system, but through the song the shifting point has emerged.

Then, monologue in song lyric is, somehow, used to express personal feeling or a reflection on life. It puts the listener as the third person to reflect as the first person. It bridges relation between the singer and the listener as the center disposition. There are, however, Dangdut songs lyric which put dialogue within the singers. This dialogical speech is in Ngidam Pentol and Kebelet songs. The dialogue occurs between a couple; a man and a woman. From the expressions, it indicates that they are spouse.

In Ngidam Pentol, the interactive dialogue such as:

The man : "Bojoku meteng telung wulan" (My wife is three months pregnant) 
The woman : "Iki ngono perbuatanmu, mas" (It was because of you, darling)

In Kebelet, the dialogue is shown below: The man : "Dik, awakmu mrinio. Nyedak'o ojok adoh-adoh" (Honey, come closer. Don't be too far from me)

The woman :"Cak, omongku rungokno. Tak critani pekarane iki" (Darling, listen to me. I will tell you something)

The lyrics in some Dangdut songs in this study are served in narrative style. The narration flows like a story with introduction, crisis and with/without ending. It retells the narration of someone who involved in love story. It is shown in Hamil Duluan, Maaf, kamu hamil duluan and Mucikari Cinta. Hamil duluan starts with the activity of kissing, then Hugging, until doing sexual intercourse in one fine night. The story reaches the crisis as the woman is pregnant. Then, she gets lost of it. Maaf, kamu hamil duluan is, somewhat, giving response to the previous song. The main character is the man who did it with a woman. He retells the same story of sexual activity they have done, until the woman gets pregnant. Mucikari Cinta tells about a story of a woman who is deceived by her husband. After such a struggle to get the woman, the man sells the woman. He makes her wife as a prostitute. At the last line of the lyric, the woman asks for help. Written like poem, song lyrics also have rhyme. Text is a great poem by itself (Hsu \& Su, 2014). Rhyme is one essential element of lyric. It ends the line with certain pattern; phonological speech. It sounds better. In Mobil Bergoyang, the rhyme AA-A-B-B is shown in the following lyric:

Setiap malam di pinggir pantai, mobil bergoyang

Tidak di pantai, tidak di hotel, orang bergoyang

Setiap malam di bawah lampu yang remang-remang

Ada patrol tapi tak peduli

Yang penting hepi
These rhymes create balance in term of sound and the choice of words. The writer of the song chooses words that have same sound at the end of the word without losing the preferred meaning he needs to deliver. In Becekin Adek, Bang, the rhyme is using A-A-A-A

becekin adek dong abang, adek goyang abang pun goyang

sawerin adek dong abang, adek senang abang pun senang daripada becek hujan-hujanan mending becek sama biduan

Rhetorical question exists in the song Melanggar Hukum. The question lies in the first line, third line and the eighth line. Line one uses Yes/No question. It is repeated in line eight. It says "Apakah aku telah melanggar hukum?" or "Have I broken the law?" The third line says "Adakah undangundang yang melarangnya?" or "is there law act that forbid it?" This question is utilized in order to make sure that what the woman did is right or wrong. She is in love with a married man. She knows that loving a married man is false. She understands the pain that the wife suffers from. She knows how hurt it is in to be the wife. Later, she confirms that she stole the man from the wife by stating "telah kurampas kebahagiannya" at the end of the lyric.

Incomplete structure exists in Dangdut song. For example, in Ada yang Panjang song. This title is incomplete phrase. It consists of determiner and adjective. The noun is not mentioned. The noun refers to a thing or item as the adjective is panjang or long. However, the reader or listener may get curious in referring to the lost noun. In the lyric, some lines also have the same pattern, such as Ada yang panjang, ada yang pendek, Ada yang lentur, ada yang bengkok. Ada yang dalam, ada yang cetek, Ada yang luwes, ada yang sempit. There are no nouns mentioned in the lines.

Relationship pattern among the participants: Messo level

The participants refer to people and/within the text. Fairclough (1995) defines this level as it explains the connection between 
the discursive process (production and interpretation) and the text. Thus, further analysis is viewed from the texts and the people who consume the texts.

In text analysis, there are three major points in addressing this level of structure. These points are seen from the texts pattern and its connection to each other. The points are man and woman relationship, sensual desire, and gender stereotype. The analysis of these points may not clear cut as they overlap and correlate each other.

Over 19 Dangdut songs that are used in this study all of them talk about man and woman relationship. It talks on love, affection, betrayal, adultery, physical touch and sexual desire. In Tali Kutang, the man lost his counterpart. Tali Kutang or woman underwear represents his love. Satu jam saja refers to affection that burst out in only one night dating. Mucikari Cinta tells the betrayal and the pain a woman has after her husband makes her as a prostitute. Adultery exists in Melanggar Hukum as a woman confused what to do. The relationship of a man and a woman is these songs ended up in sexual practices. Body contact is believed as love. It represents belongness. Sexual practice brings partners together, to unite them, and to commit them to one another (Lebrun, 1979).

The second point is sensual desire. Almost all the songs show sensual desire. This desire is seen from the choice of words on body contact and genital representation. It talks about physical touch and sexual desire. There are sensual words belongs to vulgarism as it exposes body and genital contact. For example: Buka Dikit Joss, ngidam pentol, wes mbok rasakne,Paling suka 69, Hamil Duluan, Maaf kamu hamil duluan, Mobil Bergoyang, Becekin Adek Bang, Apa Aja Boleh, Ada yang Panjang, Satu Jam Saja, Belah Duren, and Pengen Dibolongi. Look at the following lyric taken from Kebelet:

Dik, aku yo wis nafsu (darling, I want it) Engko bengi aku njaluk iku (let's do this tonight)
Balung karo ototku podo kaku,(my body is paralyzed)

Lekgak ngunu, ora iso turu (I can't sleep

unless we do it)

This lyric is explicitly stated the sexual desire of a man. The word nafsu is purposefully chosen to express the burst of erotic desire. The third line refers to genital erection as the indicator of sexual desire. The man asserts the woman to do it.

Not only man, woman's sexual desire is also shown in the song. In Pengen Dibolongi and Becekin Adek Bang, the woman wants to be seduced by man. The word dibolongi or do something with the 'hole' refers to woman's genital as it is in the form of hole. The word Becekin is explicitly and bravely stated as the desire to get 'wet'. The title of this song is in, definitely, asking for something or even command style.

Then, a song indicate a sexual desire negotiating sadomasochism. Sadomasochism is eroticization of pain and dominance (Ålvik, 2008). Take a look at Mucikari Cinta Lyric below:

Aku terjamah orang lain

I am touched by someone else

Kau malah merasa senang you are happy

\section{Sering engkau paksa diriku you often force me}

Untuk melayani temanmu

To make love with your friend

Bila ku menolak siksaan yang kuterima You will punish me if I won't

Tapi kamu bahagia

But, you are happy

The third point in this messo level is gender stereotype. The 19 songs in this study talk about sensuality and erotic desire. Women body is the object to satisfy this desire. It is not only in the perspective of man, but also the woman. For example, Becekin Adek, Bang. In the lyric, the woman wants to be seduced. She is aggressively asking a man 
to make her 'wet'. While in Kebelet, the man asks the woman to do sexual practice with him. Women's body is sexually addressed and exploited. In Buka Dikit Joss, something under the short skirt is what people curious of. It refers to women's genital display.

Within this discursive process, it is important to investigate the society perspective upon the 19 Dangdut koplo songs. The listeners of Dangdut song were interviewed to know how they interpret these songs. Their personal view is essential to see how these lyrics are produced and accepted.

Among 20 listeners of these songs, there are two points to address. Firstly, it is about the justifiability of the sensual content in Dangdut song. There are 16 people agreed that sensual and vulgarism in the lyrics cannot be accepted. Sensuality and sexuality is still taboo and should not be publicity consumed (Haryono, 2019). Some are afraid that these songs give bad effect on underage level, as media exposure is pervasive in people daily life (Greitemeyer, 2009). Among those 16 people who are agreed that the taboo content in dangdut lyrics cannot be accepted, 3 of them, who are dangdut singer stated that they face against dilemma if their audience asked them to sing those vulgar song in public, especially kebelet, but for the professional reason, they cannot avoid to sing that song. The vulgarism in the song lyrics has brought the ambivalence feeling within the job as a singer and the moral value they aware of. Meanwhile, 4 people see these songs as merely entertaining. They, even, see it as a need for pleasure and fantasy. The burden they have can be lifted although only for a while. There is something important to see in their perception about the sensual dangdut lyrics that mostly the people who state that the lyrics are entertaining are the people who listen to dangdut most of the time and use dangdut in their playlist song. Those people are commonly listen to dangdut song every day since their childhood. Those reasons seem influence their perception of sensual dangdut lyrics as a common one instead of the moral value breaking in Indonesia. Secondly, the economy motive is at attention. There are 15 listeners argued that economy is the factor behind the composing of the lyrics. They put attention on the popularity and economical reason as the first reason. They see that these controversial songs trigger curiosity and thus will gain popularity among others.

Sociocultural phenomena reflection: Macro Level

There are two points to reflect on the sociocultural phenomena. They are free sex phenomena and the position of women in the society. This macro level is drawn from the production and interpretation of the text in messo level.

Halliday (1978) highlighted the interconnection between the grammatical system and the social and personal needs that language is required to serve (Wodak and Meyer, 2001). Text is composed based on the personal needs as a reflection of social basis. What happen in the society shapes the perspective of the writer of the songs.

These sensually written lyrics are the representation of free sex phenomena (Decker, 2016). The finding in micro and messo level of structure is clearly shown that sexual practice is described as something the society is familiar with. Although some people see it as taboo, but the reality is there. These songs have exposed the undercover social reality on free sex. The body contact, relationship between men and women, erotic desire, adultery, regrets are the clue for us to reflect on.

Setiawan and Hulum (2016) argues that women are socially made as domestic needs. Their contribution within the family at home is ultimate. All domestic work is in the hand of a woman. They should be at home to cook, raise child and do good on the bed. Women are subordinate among men dominance. Men can reach their dream and do anything outside while women still 
kept inside. Sex is biologically created, while gender is socially constructed and 'cultural convention'(McConnell-Ginet, 2006). The position of women indicates that gender stereotyping still exist in Indonesian society and the sensual Dangdut songs reflect the position of women within society. In the lyrics, women body is seen as the object for men's pleasure. Body contact on women satisfies the erotic desire of men. This will lead the interpretation of the listener toward gender stereotype.

\section{CONCLUSION}

According to research questions, there are three conclusions can be drawn on:

1) In micro level, there are seven points to address on language expression and linguistics feature. The song lyrics use both Bahasa Indonesia and Javanese, figurative language, dialogue and monologue, narrative text, rhymes, rhetorical question, seducing expression, and incomplete sentence structure.

2) In Messo level, there are three major points to address. These points are seen from the texts pattern and its connection to each other. The songs talk about man and woman relationship, sensual desire, and gender stereotype. The relationship between participants can be analyzed through interview. Among 20 listeners of these songs, there are two points to address. They are the justifiability of the sensual content in Dangdut song and economy motive behind the songs.

3) In macro level, there are two points to reflect on the sociocultural phenomena. They are free sex phenomena and the position of women in the society. The songs indicate the free sex reality within the society although some see it as taboo to talk about. The songs also reveal the subordinate position of women within society. In the lyrics, women are the object for men's pleasure and satisfy the erotic desire of men.

\section{BIBLIOGRAPHY}

[1] Ålvik, J. M. B. (2008). Modalities of Desire.

[2] Bader, S. (2011). Negotiating nyawer encounters at, (February 2014), 3741.

https://doi.org/10.1080/13639811.20 11.614085

[3] Barker, T., \& Barker, T. (2011). Dangdut , the sound of Indonesia, (57), 2011.

[4] Decker, A. L. (2016). Performing Gender to Dangdut's Drum: Place, Space, and Infrastructure in Indonesian Popular Music.

[5] Eight, C. (2014). Seductive pleasures, eluding subjectivities: some thoughts on, (2000).

[6] Fairclough, N. (n.d.). Analysing Discourse: Textual Analysis for Social Research.

[7] Fairclough, N. (1993). Discourse and Social Change. Cambridge: Polity Press.

[8] Fairclough, N. (1995). Critical Discourse Analysis; The critical study of language. London: Longman.

[9] Flowerdew, J. (1999). Description and interpretation in critical discourse analysis. Journal of Pragmatics, 31, 1089-1099.

[10] Greitemeyer, T. (2009). Effects of songs with prosocial lyrics on prosocial thoughts, affect, and behavior. Journal of Experimental Social Psychology, 45(1), 186-190. https://doi.org/10.1016/j.jesp.2008.0 8.003

[11] Handforth, R., Paterson, L. L., Coffey-glover, L., \& Mills, S. (2017). Reading between Blurred Lines: The complexity of interpretation. Discourse, Context \& Media, 20, 103-115. https://doi.org/10.1016/j.dcm.2017.0 9.001

[12] Haryono, S. (2019). Dangdut dan Eksploitasi Seks Perempuan.

[13] Hsu, H., \& Su, L. I. (2014). Love in disguise: Incongruity between text and music in song. Journal of 
Pragmatics, 62, 136-150. https://doi.org/10.1016/j.pragma.201 3.10 .002

[14] Johan, A. (2018). Dangdut Stories : A Social and Musical History of Indonesia's Most Popular Music ( review ), (January 2012).

[15] Lebrun, Y. (1979). Language and Sexuality. Language Sciences, 1, 294-300.

[16] Leeuwen, V. T. (2006). Critical Discourse Analysis. Elsevier, (2001), 290-294.

[17] McConnell-Ginet, S. (2006). Book reviews Language and Sexuality. Journal of Pragmatics, 38, 444-452. https://doi.org/10.1016/j.pragma.200 5.03.003

[18] Putri, G. D. K. (2018). Negotiating dangdut sexuality: A glance through female audiences' music enjoyment.

[19] Rachmawati, N. A. (2012). Pemaknaan Lirik Lagu "Mobil Bergoyang." Universitas Pembangunan Nasional.

[20] Rahayu, B. A. (2018). Dangdut Music Affects Behavior Change at School and Adolescent Youth in Indonesia: A Literature Review Search strategy, $10-13$.

https://doi.org/10.21767/1791809X.1000552

[21] Rogers, R., \& Mosley, M. (2008). A critical discourse analysis of racial literacy in teacher education. Linguistics and Education, 19, 107-
131.

https://doi.org/10.1016/j.linged.2008. 02.002

[22] Sari, Y., \& Hanum, A. (2018). FIGURATIVE LANGUAGE USED IN THE LYRICS OF AYU TING TING' S SONGS, (April), 18-19.

[23] Setiawan, S., \& Hulum, Y. S. (2016). Pesan Dari Slebor: Analisis Wacana Kritis Terhadap Fenomena Bahasa Tulis Stiker Sepeda Motor. Paramasastra, 3(September 2016).

[24] Sriwimon, L., \& Jimarkon, P. (2017). Applying Critical Discourse Analysis as a conceptual framework for investigating gender stereotypes in political media discourse. Kasetsart Journal of Social Sciences, 1-7. https://doi.org/10.1016/j.kjss.2016.04 .004

[25] Street, B. V, \& Lefstein, A. (2007). Literacy: An Advanced Resource Book. London: Routledge.

[26] Tandho, B., \& Rohidi, T. R. (2018). Dangdut Koplo Las Vegas Pati: The Analysis of Song form Structure and Creativity of Process, 7(1), 124-131.

[27] Wallach, J. (2003). Relieving Stress, Resisting Desire: Gendered Exchange at Jakartan Dangdut Performances Jeremy Wallach, 1-12.

[28] Wodak, Ruth and Meyer, M. (2001). Methods of Critical DIscourse Analysis. New Delhi: SAGE.

\section{Author Profile}

Slamet Setiawan is a lecturer in State University of Surabaya. He obtained his MA at the University of Auckland, New Zealand in 2001 and his Ph.D at the University of Western Australia in 2013 (both in Linguistics). His interest is in Sociolinguistics: Language maintenance\&shift and Children's language in a bilingual community 